\title{
Rola biegłego rewidenta w procesie przekształceń spółek
}

\author{
Maria Kiedrowska*
}

\begin{abstract}
Streszczenie: $\mathrm{Cel}$ - Artykuł ma celu przedstawienie procesu badania planu przekształcenia spółek i roli biegłego rewidenta w tym zakresie. Aktualne przepisy zawarte w kodeksie spółek handlowych, regulacjach dotyczących rewizji finansowej są niejednoznaczne, co prowadzi do różnych interpretacji zakresu przeprowadzonego badania, stosowanych procedur i treści wydanej opinii. Metodologia badania - Analiza aktów prawnych i badania literaturowe.

Wynik - W artykule zaprezentowano wybrane problemy związane z wyceną i sporządzaniem sprawozdania finansowego na potrzeby planu przekształcenia spółek oraz procedurę badania planu przez niezależnego biegłego rewidenta.

Oryginalność/wartość - Podjęto stosunkowo rzadko i pobieżnie prezentowane zagadnienie udziału i roli biegłego rewidenta w procesie przekształceń spółek.
\end{abstract}

Słowa kluczowe: plan przekształcenia, biegły rewident, sprawozdanie finansowe

\section{Wprowadzenie}

Jednostki mogą prowadzić działalność gospodarczą w różnych formach organizacyjno-prawnych. W ostatnich latach można zaobserwować duży wzrost liczby przekształceń spółek. Przyczyny zmiany formy prawnej mogą mieć charakter ekonomiczny lub prawny. Przyczyny ekonomiczne wynikają z chęci wyższej efektywności gospodarowania, natomiast prawne powstają, gdy spełnienie określonych warunków nie jest możliwe w danym typie spółki i konieczne jest dokonanie przekształcenie (Witosz 2013: 324-325).

W celu zagwarantowania bezpieczeństwa obrotu gospodarczego, dla wspólników i akcjonariuszy przekształcanych spółek oraz wierzycieli w polskim prawie zawarto określone specjalne procedury przekształcenia spółek. Zostały one zawarte w dziale III tytuł IV Kodeksu spółek handlowych (ksh). Podstawowym walorem przekształcenia spółek zgodnie przepisami Kodeksu spółek handlowych jest zmiana formy organizacyjnej bez konieczności przerywania dotychczasowej działalności spółki i bez konieczności przeprowadzania procesu likwidacji.

Przeprowadzenie przekształcenia wymaga opracowania planu przekształcenia, który, dla zwiększenia wiarygodności zawartych w nim informacji, jest obowiązkowo badany

\footnotetext{
* dr Maria Kiedrowska, Uniwersytet Ekonomiczny w Poznaniu, al. Niepodległości 10, 61-875 Poznań, e-mail: maria.kiedrowska@ue.poznan.pl.
} 
przez biegłego rewidenta. Badanie to należy zaliczyć do usług poświadczających (atestacyjnych) świadczonych przez biegłych rewidentów. Niejednoznaczność regulacji w tym zakresie powoduje różną ich interpretację między innymi co do podstawy prawnej i zakresu przeprowadzanego badania, stosowanych procedur badawczych czy treści wydawanej opinii.

Celem artykułu jest przedstawienie roli biegłego rewidenta w procesie przekształceń spółek oraz problemów wynikających z nadmiernej ogólności i nieścisłości regulacji prawnych.

\section{Podstawy prawne przekształcenia spółek}

Prawne aspekty przekształcenia spółek reguluje Kodeks spółek handlowych. Zawiera on przepisy ogólne dotyczące przekształceń wszystkich spółek (art. 551 §1-570) oraz dodatkowe regulacje właściwe dla określonego typu przekształceń. Kodeks spółek handlowych (ksh) przewiduje możliwość przekształcenia:

- spółki osobowej w spółkę kapitałową (art. 571-574),

- spółki kapitałowej w spółkę osobową (art. 575-576),

- spółki kapitałowej w inną spółkę kapitałową (art. 577-580),

- spółki osobowej w inną spółkę osobową (art. 581-584),

- a także przekształcenie przedsiębiorcy w spółkę kapitałową (art. 5841 $-584^{13}$ ).

W świetle obecnych regulacji istnieje możliwość przekształcenia spółki jawnej, spółki partnerskiej, spółki komandytowej, spółki komandytowo-akcyjnej, spółki z ograniczoną odpowiedzialnością, spółki akcyjnej (nazywanej spółką przekształcaną) w inną spółkę handlową (spółkę przekształconą). Spółka cywilna może być przekształcona w spółkę handlową, inną niż spółka jawna.

Spółce przekształconej, zgodnie z powyższymi regulacjami, przysługują wszystkie prawa i obowiązki spółki przekształcanej, na spółkę przekształcaną przechodzą zatem zezwolenia, koncesje i ulgi, które zostały przyznane spółce przed jej przekształceniem. Spółka przekształcona powstaje $\mathrm{z}$ chwilą wpisu do rejestru, w tym samym czasie zostaje wykreślona spółka przekształcana. Wcześniej jednak konieczne jest:

- sporządzenie planu przekształcenia spółki wraz z załącznikami oraz opinią biegłego rewidenta,

- powzięcie uchwały o przekształceniu spółki,

- powołanie członków organów spółki przekształconej albo określenia wspólników prowadzących sprawy tej spółki i reprezentujących ją,

- zawarcie umowy albo podpisanie statutu spółki przekształconej.

Z ekonomicznego punktu widzenia uchwała o przekształceniu spółki powinna zawierać informację o wysokości kapitału zakładowego, w przypadku przekształcenia w spółkę z ograniczoną odpowiedzialnością bądź spółkę akcyjną - albo o wysokości sumy komandytowej (gdy przekształcenie w spółkę komandytową), wartości nominalnej akcji (gdy przekształcenie w spółkę komandytowa akcyjną), a także o wysokości kwoty przeznaczonej 
na wypłaty dla wspólników nieuczestniczących w spółce przekształconej, która nie może przekraczać $10 \%$ wartości bilansowej majątku spółki. Wspólnicy, którzy chcą uczestniczyć w spółce przekształconej, muszą złożyć pisemne oświadczenia. Wspólnik, który nie złoży oświadczenia o uczestnictwie w spółce przekształconej, może otrzymać wypłatę kwoty odpowiadającej wartości udziałów/akcji w spółce przekształcanej zgodnie ze sprawozdaniem finansowym sporządzonym dla celów przekształcenia. Jeśli wspólnik ma zastrzeżenia do rzetelności wyceny udziałów albo akcji, przyjętej w planie przekształcenia, to powinien to zgłosić najpóźniej w dniu powzięcia uchwały o przekształceniu, żądając ponownej wyceny wartości bilansowej swoich udziałów albo akcji (art. $566 \S 1$ ksh).Gdy spółka nie uwzględni żądania w terminie dwóch miesięcy od dnia jego wniesienia, to wspólnik może wnieść powództwo o ustalenie wartości udziałów/akcji.

Procedury przekształcenia spółek uregulowane są także m.in. w prawie bilansowym i prawie podatkowym. Regulacje prawa bilansowego w zasadzie sprowadzają się wyłącznie do określenia wymogów dotyczących zamykania i otwierania ksiąg rachunkowych w jednostkach przekształcanych.

\section{Elementy planu przekształcenia spółek}

Jednym z warunków przeprowadzenia przekształcenia spółki jest przygotowanie planu przekształcenia. Plan przekształcenia przygotowuje zarząd spółki przekształcanej albo wszyscy wspólnicy prowadzący sprawy spółki przekształcanej (art. 557 § 1 ksh). Plan przekształcenia sporządza się w formie pisemnej (w spółce jednoosobowej w formie aktu notarialnego).

Zgodnie z art. $558 \S 1$ Kodeksu spółek handlowych plan przekształcenia zawiera co najmniej:

- ustalenie wartości bilansowej majątku spółki przekształcanej na określony dzień w miesiącu poprzedzającym przedłożenie wspólnikom planu przekształcenia, oraz

- określenie wartości udziałów albo akcji wspólników zgodnie ze sprawozdaniem finansowym sporządzonym dla potrzeb przekształcenia, które jest dołączone do planu przekształcenia.

Jako załączniki do planu przekształcenia traktowane są: projekt uchwały w sprawie przekształcenia spółki, projekt umowy albo statutu spółki przekształconej, wycena składników majątku (aktywów i pasywów) spółki przekształcanej oraz sprawozdanie finansowe sporządzone dla celów przekształcenia, przy zastosowaniu takich samych metod i w takim samym układzie, jak ostatnie roczne sprawozdanie finansowe. Sprawozdanie to sporządza się na określony dzień, w miesiącu poprzedzającym przedłożenie wspólnikom/akcjonariuszom planu przekształcenia.

Z powyższego wynika, że podstawowym elementem planu przekształcenia jest ustalenie wartości majątku spółki przekształcanej. Majątek ten jest ustalany na podstawie bilansu i odzwierciedla aktywa netto spółki przekształcanej. Aktywa netto to aktywa spółki 
nieobciążone długami. Oblicza się je jako różnię między aktywami (trwałymi i obrotowymi) a zobowiązaniami i rezerwami na zobowiązania, co oznacza, że aktywa netto odpowiadają wartościowo kapitałom własnym spółki.

Wartość majątku (aktywów netto) jest podstawą do ustalenia kwot, jakie mogą otrzymać wspólnicy/akcjonariusze, którzy rezygnują z uczestnictwa w spółce przekształconej i wystąpią z roszczeniem o wypłatę udziałów/akcji posiadanych w spółce przekształcanej. Ponadto ustalenie wartości aktywów netto (kapitałów własnych) spółki przekształcanej pozwala stwierdzić, czy wspólnicy/akcjonariusze posiadają dostateczne środki na pokrycie wymaganego prawem, ustalonego w statucie czy umowie spółki, kapitału zakładowego w spółce przekształconej.

Nie ulega wątpliwości, że przyjęcie przez jednostkę określonych zasad wyceny aktywów i pasywów zawartych w sprawozdaniu finansowym wpłynie na wartość majątku, tym samym na wartość kapitałów własnych a w konsekwencji na wartość udziałów lub akcji wspólników spółki przekształcanej. Z zapisu art. 558 § 1 ust. 4 ksh wynika, że aktywa i pasywa w bilansie sporządzanym na potrzeby przekształcenia należy wycenić według tych samych zasad i metod, które jednostka przyjęła w swojej polityce rachunkowości w zgodzie z wymogami zawartymi w art. 28 ustawy o rachunkowości. W przypadku wyceny aktywów na dzień bilansowy ustawa zawiera często rozwiązania alternatywne, które pozwalają na wybór jednego z wariantów wyceny. Przykładowo, posiadane grunty wykorzystywane na własne potrzeby i zaliczone do środków trwałych jednostka musi wycenić po cenie nabycia, z uwzględnieniem ewentualnej trwałej utraty ich wartości, natomiast w przypadku gruntów zaliczonych do nieruchomości inwestycyjnych jednostka może przyjąć wycenę właściwą do środków trwałych lub według ceny rynkowej bądź inaczej określonej wartości godziwej. Jeśli jednostka wybierze wariant wyceny tych nieruchomości po cenie nabycia, to w przypadku wzrostu wartości nieruchomości na rynku prowadzi to do zaniżenia wartości posiadanego majątku i tworzenia tzw. „,ichych rezerw”. Wycena aktywów co najwyżej po cenie nabycia lub koszcie wytworzenia może być właściwa, ale tylko z punktu widzenia właścicieli, którzy przejmują udziały czy akcje w spółce przekształconej. Z punktu widzenia współwłaściciela, który rezygnuje z udziałów w spółce przekształconej może to być wysoce krzywdzące.

Należy zwrócić uwagę, że spółka sporządzająca sprawozdanie dla celów przekształcenia nie ma obowiązku przeprowadzenia inwentaryzacji (art. 26 ustawy o rachunkowości), co może przyczynić się do wykazania niezgodnej z prawdą wartości aktywów. Pomimo braku obowiązku przeprowadzenia inwentaryzacji spółka przekształcana powinna dokonać spisu z natury produkcji w toku, zapasów obciążających koszty jednostki z chwilą zakupu (materiały i towary) lub wytworzenia (wyroby gotowe), a także robót budowlanych zaliczanych do kontraktów długoterminowych.

Znacznym problem może być ustalenie wartości bilansowej majątku przekształcanej spółki, która nie prowadzi ksiąg rachunkowych. Jednostka taka nie tylko nie posiada 
polityki rachunkowości, ale i nie prowadzi pełnej ewidencji aktywów i pasywów. Stan aktywów i pasywów w bilansie otwarcia takiej jednostki zależeć będzie od rzetelności przeprowadzonej inwentaryzacji i przyjętych zasad wyceny.

Do planu przekształcenia spółka powinna dołączyć także wycenę składników majątku (aktywów i pasywów). W przypadku tego elementu planu przekształcenia występuje brak zgodności, w jakich cenach i w jakim celu jest dokonywana wycena. Zdecydowana większość autorów uważa, że wycena aktywów i pasywów jest sporządzana na potrzeby sprawozdania finansowego i musi być przeprowadzona zgodnie z zasadami rachunkowości określonymi w art. 28 ustawy o rachunkowości i przyjętą polityką rachunkowości (Kwasiborski 2008: 12). Spotkać można także pogląd, że wycena aktywów i pasywów jest dokonywana na poziomie wartości rynkowej (godziwej) i niezależnie od sprawozdania finansowego sporząazanego dla celów przekształcenia. Wycena ta pozwala ocenić realność wnoszonego majątku i nie służy do określenia opłaty wspólników nieprzystępujących do przekształconej spółki (Szymański 2009). Należy przypuszczać, że wartość aktywów i pasywów wycenionych według wartości rynkowej będzie wyższa od wyceny bilansowej, a to spowodować może powstanie roszczeń wspólników nieprzystępujących do przekształcanej spółki.

W przypadku przekształcania spółki jawnej, w której wszyscy wspólnicy prowadzili sprawy spółki, można zastosować uproszczenie procedury ograniczając ją do przygotowania dokumentów będących załącznikami do planu przekształcenia.

\section{Plan przekształcenia spółek jako przedmiot badania biegłego rewidenta}

Zgodnie z art. $559 \S 1$ ksh plan przekształcenia spółki musi być zbadany przez biegłego rewidenta w zakresie poprawności i rzetelności. Plan przekształcenia jest poprawny, gdy spełnia wszystkie wymogi formalne, w przypadku rzetelności biegły ocenia wartość merytoryczną prezentowanych w nich informacji. Biegłego rewidenta wyznacza sąd rejestrowy właściwy według siedziby spółki przekształcanej i czyni to na wniosek spółki. W uzasadnionych przypadkach może wyznaczyć dwóch albo większą liczbę biegłych. Zapis ten rodzi wątpliwości, czy spółka przekształcana, składając wniosek do sądu o wyznaczenie biegłego, przedkłada plan przekształcenia, a jeśli tak - to ile egzemplarzy? Opinie prawników na ten temat nadal są różne. Niektórzy uważają, że spółka powinna złożyć do sądu jednocześnie plan przekształcenia i wniosek o wyznaczenie biegłego zaproponowanego przez spółkę, inni, że składając wniosek o wyznaczenie biegłego nie składa się planu przekształcenia (Miroszewski 2002). Słusznym wydaje się stanowisko A. Stępień, która stwierdza, że złożenie planu przekształcenia do sądu jest konieczne tylko w sytuacji, gdy spółka powierza sądowi wybór biegłego rewidenta (Stępień 2006: 51). W praktyce dzieje się tak, że spółka przekształcana składa wniosek do sądu o wyznaczenie konkretnego biegłego. W spółkach, które podlegają obowiązkowemu badaniu zwykle jest to biegły rewident, który bada ich 
roczne sprawozdanie. Podstawową zaletą takiego rozwiązania jest: dla spółki - ograniczenie czasu i kosztów badania, dla biegłego - zmniejszenie ryzyka wydania niewłaściwej opinii.

Celem badania planu przekształcenia jest wydanie opinii dla akcjonariuszy/wspólników przekształcanej spółki, że zarząd przekształcanej spółki przygotował plan przekształcenia spółki zgodnie z obowiązującym prawem, prawidłowo i rzetelnie ustalił wartość bilansową majątku spółki przekształcanej oraz wartość udziałów/akcji wspólników (Bielak i in. 2002: 96).

Biegły rewident powinien tak zaplanować i przeprowadzić badanie, by uzyskać wystarczającą pewność, że plan przekształcenia spółki jest wolny od istotnych nieprawidłowości.

W procedurze badania planu przekształcenia wyodrębnić można następujące etapy:

- zawarcie umowy o badanie planu przekształcenia się spółek,

- opracowanie planu i strategii badania,

- przeprowadzenie badania,

- przegląd zdarzeń po dacie sporządzenia planu przekształcenia,

- sporządzenie pisemnej opinii o planie przekształcenia spółek.

Przed zawarciem umowy biegły rewident powinien przeprowadzić procedury akceptacji usługi, stwierdzając m.in. czy podejmując się tego badania, zachowa niezależność i bezstronność oraz czy posiada odpowiednie kwalifikacje. Umowa dotycząca badania planu połączenia powinna określać co najmniej zakres usługi, obowiązki strony zlecającej, w tym m.in. udostępnienie planu przekształcenia wraz załącznikami, obowiązki biegłego rewidenta i wysokość wynagrodzenia.

Podobnie jak w badaniu rocznego sprawozdania finansowego ważnym, choć nadal niedocenianym, elementem procesu badania jest planowanie i opracowanie strategii badania. Na tym etapie biegły powinien m.in. oszacować ryzyko badania, ustalić kwoty istotności, ewentualnie ustalić członków zespołu przeprowadzających badanie, opracować szczegółowy plan i harmonogram badania. Czas i zakres badania właściwego w znacznej mierze zależeć będą od oszacowania ryzyka badania, w tym ryzyka istotnego zniekształcenia. Na poziom wyznaczonego ryzyka wpływ będą miały kwalifikacje osób opracowujących plan przekształcenia, korzystanie z pomocy doradców podatkowych i prawników, kwalifikacje pracowników księgowości, znajomość badanej jednostki. Poziom ryzyka rośnie, gdy przekształcana spółka nie podlega obowiązkowemu badaniu bądź nie prowadzi ksiąg rachunkowych.

W trakcie badania właściwego biegły rewident powinien ustalić:

- czy plan przekształcenia zawiera wszystkie elementy i załączniki wymagane w kodeksie spółek handlowych,

- czy załączniki są spójne z planem przekształcenia i czy są przygotowane zgodnie z ksh,

- sprawozdanie finansowe sporządzone dla celów przekształcenia,

- poprawność ustalenia wartości udziałów i akcji. 
W tym momencie należy zadać pytanie, czy badanie planu przekształcenia (w tym wyceny aktywów i pasywów oraz sprawozdania finansowego) jest tożsame $\mathrm{z}$ badaniem rocznego sprawozdania finansowego. $Z$ zapisu art. $558 \S 4$ pkt 4 ksh wynika, że sprawozdanie finansowe jest przede wszystkim sporządzane w celu ustalenia wartości majątku spółki przekształcanej, będącego podstawą do określenia wartości udziałów/akcji. Sprawozdanie to nie podlega, tak jak sprawozdanie roczne, zatwierdzeniu przez wspólników w trybie art. 53 ustawy o rachunkowości. W przypadku planu przekształcenia badanie sprawozdania finansowego ma charakter usługi poświadczającej, a zatem nie można go porównywać $\mathrm{z}$ badaniem rocznego sprawozdania finansowego (Kwasiborski 2002: 115). Zakres i procedury takiego badania są uproszczone. Badanie sprawozdania finansowego polega m.in. na sprawdzeniu powiązania zapisów księgowych na kontach z odpowiednimi pozycjami bilansu i rachunku zysków i strat, poprawności wyceny aktywów i pasywów i zgodności z polityką rachunkowości spółki. Obarczone szczególnym ryzykiem jest badanie sprawozdania finansowego sporządzonego przez jednostkę, która nie prowadzi ksiąg rachunkowych.

Następnie biegły sprawdza prawidłowość ustalenia wartości udziałów/akcji. Nierzetelne ustalenie wartości udziałów/akcji daje wspólnikowi/akcjonariuszowi prawo do żądania ponownej wyceny wartości bilansowej udziałów/akcji. Z kolei błędna wycena bilansowa majątku w spółkach osobowych może spowodować, że nieprawidłowo zostanie ustalony udział kapitałowy właścicieli.

Przed wydaniem opinii biegły rewident powinien dokonać przeglądu zdarzeń po dacie sporządzenia planu i ocenić ich wpływ na sprawozdanie finansowe i wycenę udziałów lub akcji wspólników spółki przekształcanej. W przypadku wystąpienia zdarzeń, które mają istotny wpływ na wartość bilansową majątku, a tym samym udziałów/akcji, należy rozważyć wprowadzenie korekt do sprawozdania finansowego i innych powiązanych z nim elementów planu przekształcenia.

\section{Opinia z badania planu przekształcenia spółki}

Biegły rewident, w terminie wyznaczonym przez sąd, ale nie dłuższym niż dwa miesiące od dnia jego wyznaczenia, sporządza szczegółową opinię na piśmie i składa ją wraz z planem przekształcenia sądowi rejestrowemu oraz spółce przekształcanej.

Jak już wcześniej wspomniano, badanie planu przekształcenia jest zaliczane do usług atestacyjnych świadczonych dodatkowo przez biegłych rewidentów. W związku z tym opinia $z$ badania planu przekształcenia nie może być wzorowana na opinii z badania rocznego sprawozdania finansowego. Ogólne elementy informacji sprawozdania z usług atestacyjnych zawiera Międzynarodowy Standard Usług Atestacyjnych - 3000. Oznacza to, że biegły rewident musi opracować treść wydawanej opinii, w zgodzie z ogólnymi założeniami powyższego Standardu. 
W przypadku planu przekształcenia, we wnioskach opinia przykładowo powinna zawierać stwierdzenia, że:

- plan przekształcenia zawiera wszystkie elementy i załączniki wymagane w ksh,

- plan przekształcenia został sporządzony prawidłowo i rzetelnie,

- sprawozdanie finansowe sporządzone dla celów przekształcenia jest we wszystkich aspektach prawidłowe i rzetelne,

- wartość bilansowa aktywów netto została ustalona prawidłowo,

- wartość udziałów lub akcji wspólników spółki przekształcanej została poprawnie ustalona w oparciu o to sprawozdanie finansowe.

Spełnienie tych stwierdzeń oznacza wydanie opinii pozytywnej (bez zastrzeżeń). Jeśli zdaniem biegłego, któreś z wymienionych stwierdzeń nie jest prawdziwe, ponieważ - na przykład - plan przekształcenia nie jest kompletny, sprawozdanie finansowe nie jest sporządzone prawidłowo i rzetelnie, wartość udziałów/akcji nie została poprawnie ustalona, to w zależności od wagi błędu, wyda opinię z zastrzeżeniem lub negatywną. W wydanej opinii musi swoje stanowisko uzasadnić. Jeśli występuje ograniczenie zakresu badania, gdyż biegły nie może zebrać wystarczających dowodów do wydania opinii, to powinien zrzec się wydania opinii.

Data wydania opinii jest jednocześnie data zakończenia badania. Opinia nie może być wystawiona $z$ datą wcześniejszą od daty planu przekształcenia.

Aby potwierdzić prawidłowość wydanej opinii, biegły rewident tworzy dokumentację z badania, zawierającą dowody badania i wnioski wyciągnięte na podstawie tych dowodów. Opinia w szczególności powinna wskazywać sposób rozumowania i wnioski biegłego w kwestiach wymagających osądu. W dokumentacji z badania planu przekształcenia powinny znaleźć się m.in. kopia wydanej opinii, postanowienie sądu rejestrowego o wyznaczeniu biegłego do zbadania planu przekształcenia, oświadczenie biegłego rewidenta o niezależności w stosunku do przekształcanej spółki, oświadczenie zarządu spółki przekształcanej o jasności, rzetelności i prawidłowości sprawozdania finansowego sporządzonego dla potrzeb planu przekształcenia oraz o kompletności i poprawności przygotowania planu przekształcenia. Ważnym elementem dokumentacji jest kopia planu przekształcenia i załączników do planu, w tym kopia sprawozdania finansowego, wykaz zauważonych nieprawidłowości, dane liczbowe uzyskane od sądu i od spółki.

\section{Uwagi końcowe}

Badanie planu przekształcenia jest zaliczane do usług atestacyjnych i jest zastrzeżone, w odróżnieniu od badania planów połączenia i planów podziału spółek, wyłącznie do kompetencji biegłego rewidenta. Efektem przeprowadzonego badania jest wyrażona przez biegłego opinia na temat rzetelności i prawidłowości planu przekształcenia. 
Badanie to jest obarczone znacznym ryzykiem wynikającym nie tylko ze złożoności różnych typów przekształceń form organizacyjno-prawnych, ale też z konsekwencji finansowych, a w szczególności podatkowych, dla właścicieli przekształcanej spółki, wynikających z niewłaściwej wyceny aktywów netto, nieprawidłowego ustalenia kapitału zakładowego przekształconej spółki. Konsekwencje wydania niewłaściwej opinii ponosi także biegły rewident, bowiem, zgodnie z prawem, odpowiada wobec spółki i wspólników spółki przekształcanej za szkody wyrządzone z jego winy.

\title{
Literatura
}

Bielak J., Kowalczuk E., Maciejewski R., Ostaszewicz A., Tomkins L., Włodarska J. (2002), Inne usługi biegłego rewidenta, zasady formułowania dokumentów finalnych, Stowarzyszenie Księgowych w Polsce, Warszawa.

Kwasiborski A. (2002), Inne usługi biegłego rewidenta, Krajowa Izba Biegłych Rewidentów, Warszawa.

Kwasiborski A. (2008), Przekształcenie spółki cywilnej lub jawnej w spótkę z o.o. Zagadnienia księgowe, „Rachunkowość" nr 10, s. 24-34.

Międzynarodowy Standard Usług Atestacyjnych 300 - Usługi atestacyjne inne niż badania lub przeglądy historycznych informacji.

Miroszewski I., (2002), Wyznaczanie biegłego rewidenta w procesie przekształcenia spółki, „Przegląd Prawa Handlowego", sierpień, s. 31-37.

Szymański K. (2009), Opodatkowanie przekształcania spółek osobowych i kapitałowych, www.lex.pl/akt/_opodatkowanie_przeksztalcenia_spolek_osobowych_i_kapitalowych (30.04.2015).

Stępień A. (2006), Przekształcenia spółek handlowych, C.H. Beck, Warszawa.

Ustawa z dnia 15 września 2000 r. Kodeks spółek handlowych, Dz.U. nr 94, poz. 1037 z późn. zm.

Ustawa z dnia 29 września 1994 r. o rachunkowości, Dz.U. z 2013 r., poz. 330.

Ustawa z dnia 7 maja 2009 r. o biegłych rewidentach i ich samorządzie, podmiotach uprawnionych do badania sprawozdań finansowych oraz o nadzorze publicznym, Dz.U. nr 77, poz. 649.

Witosz A. (2013), Eączenie, podział i przekształcanie spótek handlowych, wyd. 3, LEX a Wolters Kluwer business, Warszawa.

\section{THE ROLE OF AN AUDITOR IN TRANSFORMATION PROCESS OF COMPANIES}

\begin{abstract}
Purpose - the aim of this article is to present an audit of the transformation plan of a company and the role of an auditor in this process. The author indicates that the current rules contained in the Code of Commercial Companies and audit regulations are ambiguous which causes their different interpretations. This in turn raises differences in scopes of carried audits, applied procedures and essences of auditor's opinion. Methodology - the analysis of law regulations and literature studies. Findings - The article presents selected problems related to the valuation of the company assets and liabilities and the preparation of financial statements for the transformation plans of companies, as well as the audit procedure of the plan by an independent auditor. Originality/value - The article takles the relatively rarely presented issue of the participation and the role of an auditor in the companies transformation process.
\end{abstract}

Keywords: transformation plan, auditor, financial statement

\section{Cytowanie}

Kiedrowska M. (2015), Rola biegłego rewidenta w procesie przekształceń spótek, Zeszyty Naukowe Uniwersytetu Szczecińskiego nr 855, „Finanse, Rynki Finansowe, Ubezpieczenia” nr 74, t. 1, Wydawnictwo Naukowe Uniwersytetu Szczecińskiego, Szczecin, s. 643-651; www.wneiz.pl/frfu. 
